\title{
The wood in the forest: Why California needs to reexamine the role of biomass in climate policy
}

Peter Tittmann, Academic Coordinator, Woody Biomass Utilization Group, Center for Forestry, UC Berkeley

n California, the forestry sector and biomass energy

producers have the potential to work together to

reduce the state's net greenhouse gas emissions, reliably generate renewable electricity, provide lowcarbon building materials, support healthy forests and improve air quality.

But wood energy producers are in a precarious position. Without quick policy changes, much of the state's remaining biomass power plant capacity will soon be shut down. Roughly half of the power plants in the state that run on woody biomass are operating under power supply contracts set to expire by the end of 2016. Under current policies, it is likely that utilities will not offer new contracts at rates sufficient to cover the costs of operating these biomass plants.

The biomass energy sector's predicament stems in part from an otherwise positive development - the rapid expansion of low-cost solar photovoltaic power in California (fig. 1). Under California's Renewables Portfolio Standard (RPS), one-third of the electricity provided by the state's utilities must come from renewable sources by 2020 . To meet these goals, utilities must contract with renewable power producers such as solar power installations, wind farms or biomass power plants.

The price of electricity is a major factor in utilities' power procurement decisions. As the price of power from new solar installations has dropped - it's now in the range of 3 to 5 cents per kilowatthour less than what biomass plants can offer utilities have little incentive to renew contracts with existing biomass power plants on terms that will allow the plants to stay open.

But this simple price comparison misses two important factors. First, by incentivizing better forest management and improved forest health, biomass energy leverages considerable climate and other environmental benefits beyond the direct reductions in carbon emissions from generating electricity from a renewable resource. Second, biomass power plants provide consistent "base load" power output. Solar, by contrast, delivers intermittent power that declines in the afternoon as the demand for power peaks, complicating the management of the grid and requiring the operation of natural gas-fired "peaker" plants. This intermittency adds significant costs to the operation of the state's power system that are not reflected in solar power's low market price, but are passed on to ratepayers.

\section{Forestry and climate change}

The role of forests in climate change mitigation might seem simple: as trees grow, they remove

The Buena Vista Biomass Power facility near lone (Amador
County) generates up to 18 megawatts of electricity County) generates up to 18 megawatts of electricity
from a mix of forest slash, urban green waste and woody biomass generated by farms. 


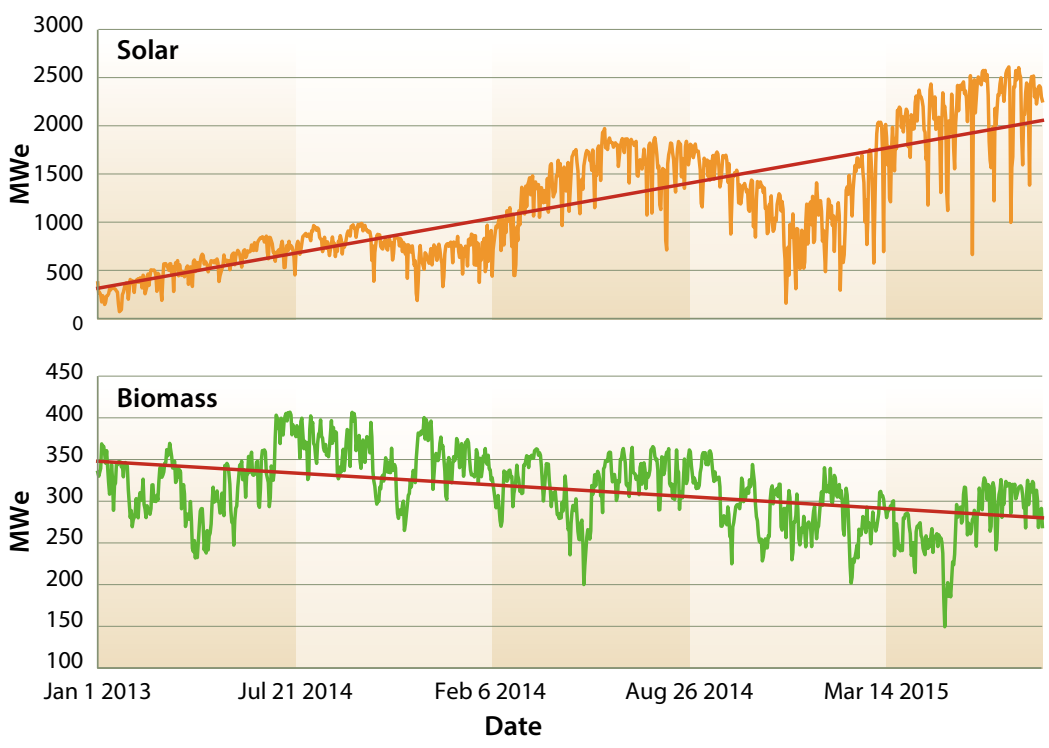

Fig. 1. Daily average power records from the California Independent System Operator show the recent increase in solar power and decrease in biomass power on the state's electricity grid. Data may include out-ofstate generation. carbon from the atmosphere and store it into their trunks, branches, roots and leaves. Simply protecting forests from agents that kill trees (insects, say, or wildfire) would appear to be a reasonable strategy to ensure that forests deliver their carbon benefit.

In reality, the role of forests in capture and storage of carbon is more complicated. According to state and federal estimates, the living trees in California's forests hold the equivalent of between 3 and 4 billion tons of carbon dioxide - around eight times the state's total annual emissions of all greenhouse gases. Maintaining or expanding this vast stock, however, depends on forests remaining healthy.
Nearly a century of wildfire suppression, in combination with the warming climate, has dramatically elevated the risk of high intensity wildfire across much of the state's forestlands. The role of fire in California's forests is similar to that of a dentist: just as frequent cleanings prevent major dental problems, so do frequent low-intensity fires prophylactically protect forest health. By consuming dead or dying trees and dead material on the forest floor, small fires reduce fuel load and thus the risk of extreme fire. Unfortunately, across much of California and the rest of the western United States, the now century-old policy of wildfire suppression has resulted in infrequent and catastrophic fire.

Some of the strongest opposition to thinning forests to reduce the fuel load comes from a few of the state's most prominent environmental groups. These groups oppose bioenergy uses of forest biomass on the grounds that catastrophic, stand-replacing fires are desirable because they leave the forest in a condition that may benefit certain species. Their opposition takes two main forms: lobbying state and federal legislators to further limit the ability of land management agencies and private landowners to actively prevent catastrophic wildfire through forest thinning and stand improvement; and pursuing legal action against community organizations' efforts to build small-scale, distributed power plants that would create markets for the limbs, brush and small trees that are thinned in the process of fire hazard reduction. Advocacy for increased levels of stand-replacing fire represents an implicit willingness to accept the impact of increased greenhouse gas emissions and lost sequestration in forests from catastrophic wildfire - the consequences of which will fall disproportionately on poor people in faraway places and residents of rural forested communities in California - as the necessary collateral to expanding the range of a particular species of interest.

Biomass power plants create a market for small trees, limbs and treetops - or what people in forestry call "slash" - generated by forest management operations such as fire hazard reduction treatments. However, the cost

The Gasquet Complex Fire, which was caused by lightning in the Six River National Forest in California on Jul. 31, had consumed over 30,000 acres as of Sep. 14. 


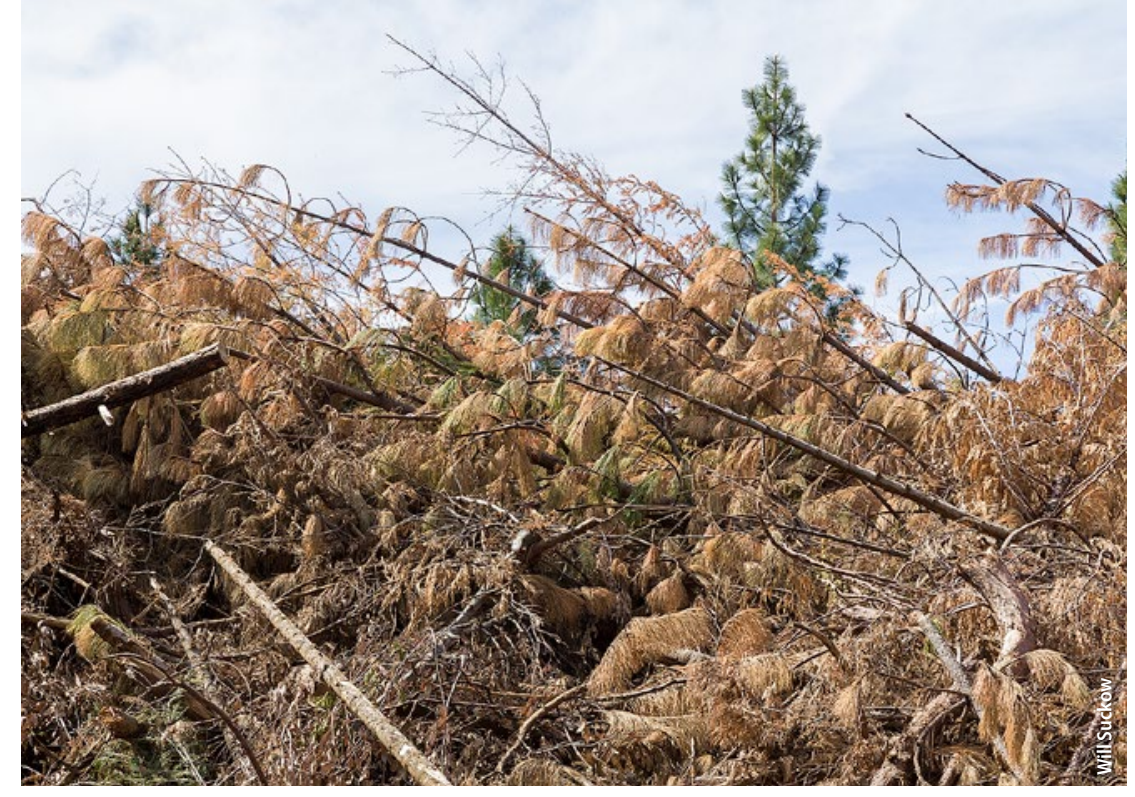

Forest slash is piled following a thinning treatment at the UC Blodgett Forest Research Station in El Dorado County.

plastics. For example, using engineered-wood I-beams for floor joists rather than steel I-beams reduces lifecycle greenhouse gas emissions by more than 9 kilograms of carbon dioxide per kilogram of wood fiber used. Thus, increasing the use of wood and woodderived products where economically feasible will have significant long-term

of conducting such treatments generally far exceeds what power plants are willing to pay for biomass fuel. Thus, while revenue from selling slash to power plants helps land managers by offsetting a portion of forest treatment costs, it does not provide a profit motive for increasing extraction of biomass from forests simply to supply power plants.

Fire hazard reduction treatments with chainsaws and forestry machines can mimic the effect of lowintensity wildfires, the kind that would have moved frequently through much of the state's forestland pre-settlement, burning smaller trees and brush but leaving larger trees alive. Such treatments can reduce fuel loads to a level that can then be maintained through low-intensity, prescribed natural fires overseen by firefighters and fire professionals. Without a biomass energy market for slash, fewer acres can be treated with the limited funds for fire hazard treatments available to land managers. In the absence of a biomass market, there is little to do with slash but to pile and burn it, erasing the climate benefit of using the biomass to generate electricity and resulting in substantial emissions of particulate matter and other air pollutants. Leaving slash on the ground, or avoiding thinning operations altogether, allows the buildup of fuels to continue and leaves the forest increasingly prone to severe fire.

In addition to natural sequestration from tree growth, a healthy forest sector contributes to meeting the state's climate goals by providing wood to California consumers. Wood's strength-to-weight ratio makes it widely appealing for use in construction. Wood is the product of photosynthesis - the metabolic sequestration of atmospheric carbon dioxide over the lifespan of a tree - and as a result, has dramatically less net greenhouse gas emissions associated with its use than other building materials used in similar applications such as concrete, steel and climate impacts at relatively low cost. Right now, most of the wood used for construction in California is not grown in California. And yet, California has some of the most rigorous standards governing timber harvests in the world. Californians should be building their homes and businesses with wood grown and harvested responsibly in their own state rather than importing wood grown in other parts of the world where California's rigorous forestry rules do not apply.

The ability for California's forest landowners to generate revenue by producing wood and forestry

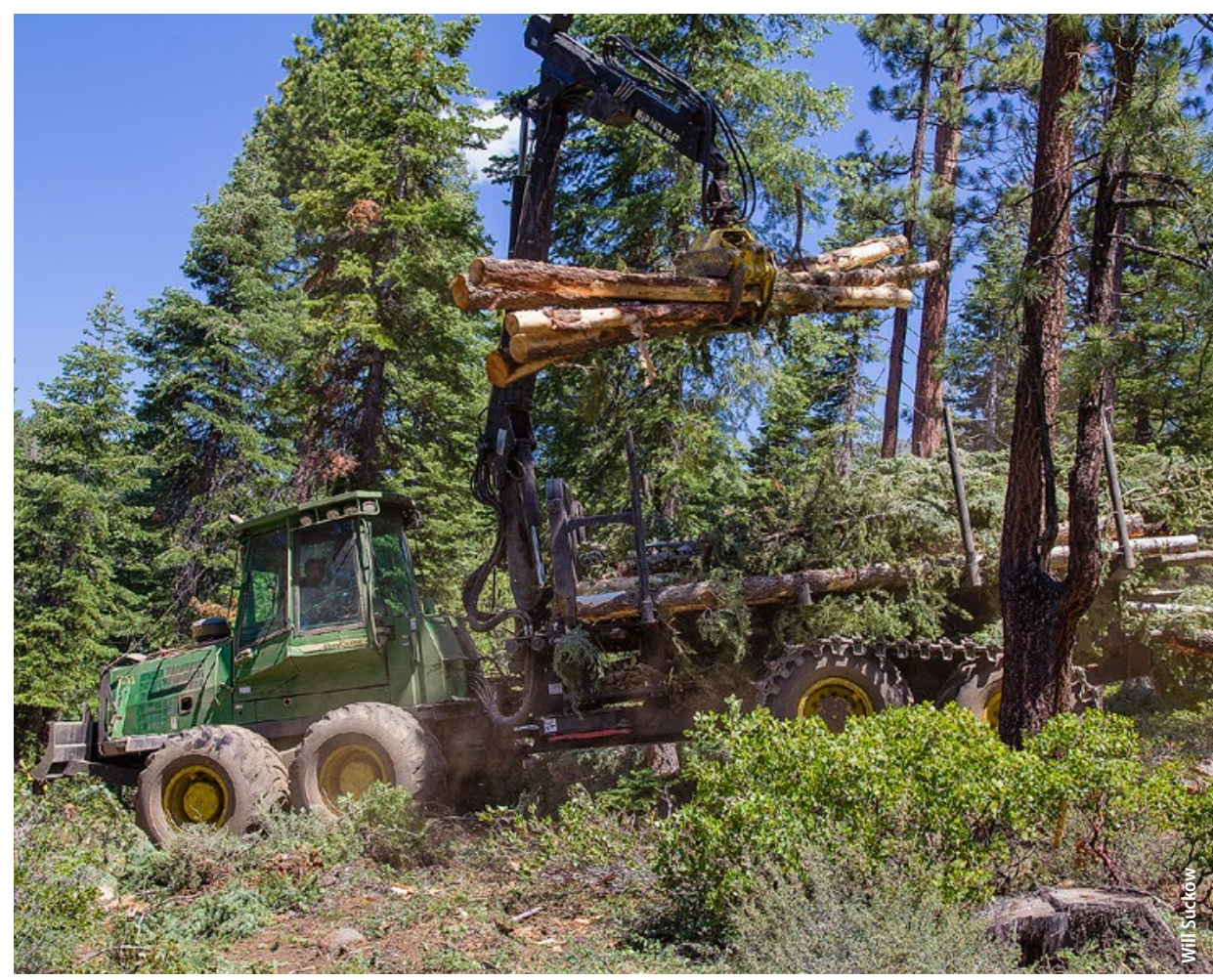

A forwarder collects forest slash for chipping at the U.S. Forest Service's Yeti Fuels Reduction project near Lake Tahoe. 
byproducts also provides an economic buffer against conversion of timberland to other, less carbondense land uses such as residential development or agriculture.

\section{Wood bioenergy: Low-hanging fruit for climate gains}

The production of electricity from wood biomass is an opportunity for low-cost, high-return climate change mitigation investment and policy. Biomass used in the state's existing fleet of biomass power plants can displace base load electricity generated by natural gas, coal or petroleum coke. Using wood to produce energy also helps to reduce the risk that carbon stored in the state's forests will be lost to fire and disease, and reduces emissions of particulate matter and black carbon from open pile burning of agricultural and forestry residues.

Other uses of forest biomass, such as conversion to biofuels or powering small-scale bioenergy plants -3 megawatts electric (MWe) capacity or less - are promising. However, compared with the existing fleet of biomass power plants, these pathways are substantially more costly and have yet to be financed and constructed.

There has been extensive debate over the net greenhouse gas benefits that can be expected by generating electricity from forest biomass, and the consensus is clear: bioenergy production using residuals from forests managed for sustained yield reduces long-term climate impact through displacement of fossil energy sources, reduced emissions from the alternative (nonenergy-producing) fates of forestry residuals, and continued sequestration from forest growth. Tahoe. Kirk Furlong Wentworth of CTL Forest Management, Inc. monitors the job.

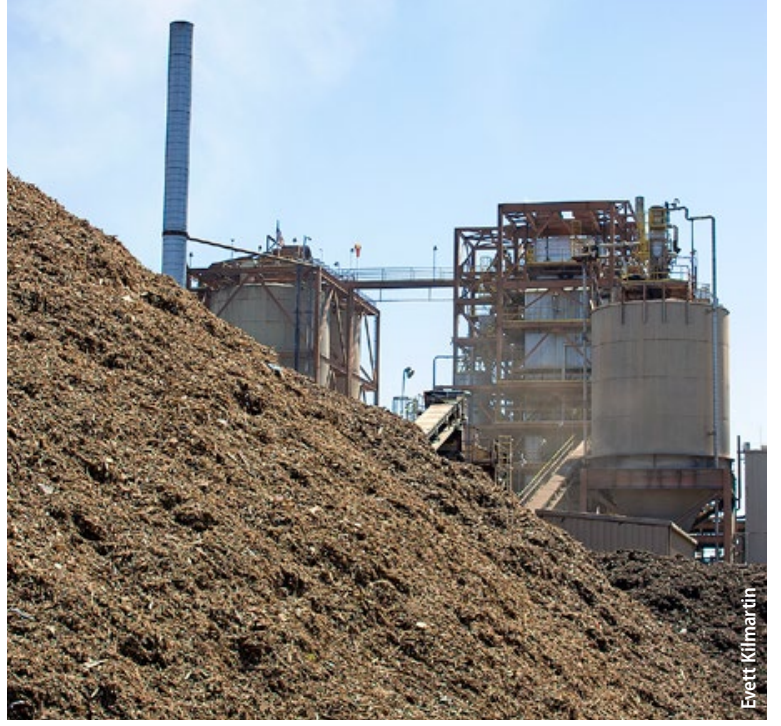

A mound of woody biomass at Buena Vista Biomass Power near lone (Amador County).

California's biomass-fueled power generation industry grew rapidly from the 1980s through the mid1990s. At the peak, close to 1,000 MWe were installed and operational. These plants, ranging in size from 7 to $50 \mathrm{MWe}$, were typically built either alongside lumber mills - so as to utilize sawdust and off-cuts from the mill and logging slash produced from harvesting — or as stand-alone plants, utilizing the wood fraction of urban waste streams (construction debris, tree prunings, etc.) and wood from orchard removals or other agricultural activities. In most cases, these plants serve the dual purposes of producing electricity and providing an alternative to incineration or landfilling of forestry, agriculture and municipal biogenic waste. In this way, the biomass energy industry has facilitated air quality improvements, landfill diversion and forest health.

Today, there is roughly 962 MWe of installed capacity for biomass power production in California. But much of that capacity is not being used to generate energy (see map on facing page). The California Independent System Operator reports a substantial reduction in electricity produced from biomass in recent years. In the current period beginning 2013, close to 100 MWe of capacity has been idled in California and annual average generation has fallen by 57 MWe (table 1). Based upon interviews with plant operators and fuel buyers, approximately 30 MWe of additional capacity is very likely to be taken offline by the end of 2016. Plant idling is most often a result of a change in the price a utility is willing to pay to a generator.

\section{Valuing the benefits of biomass electricity generation}

The price differential between solar and biomass and the resulting decline in the biomass power industry highlights a key gap in California's climate policies. The many public benefits provided by 
TABLE 1. Annual average electricity on the California Independent System Operator grid from biomass, 2012-2016

\begin{tabular}{cc}
\hline Year & Annual average MWe $^{*}$ \\
\hline 2012 & 326.6 \\
2013 & 336.6 \\
2014 & 315.3 \\
2015 & 279.6 \\
\hline
\end{tabular}

* May include out-of-state generation.

biomass power plants are not monetized through the existing RPS procurement strategy. Competition among renewable power sources based solely on the price of electricity risks missing a key opportunity for the state to use biomass energy generation to leverage major carbon benefits through better forest health, reduced fire risk and a sustainable forest products sector.

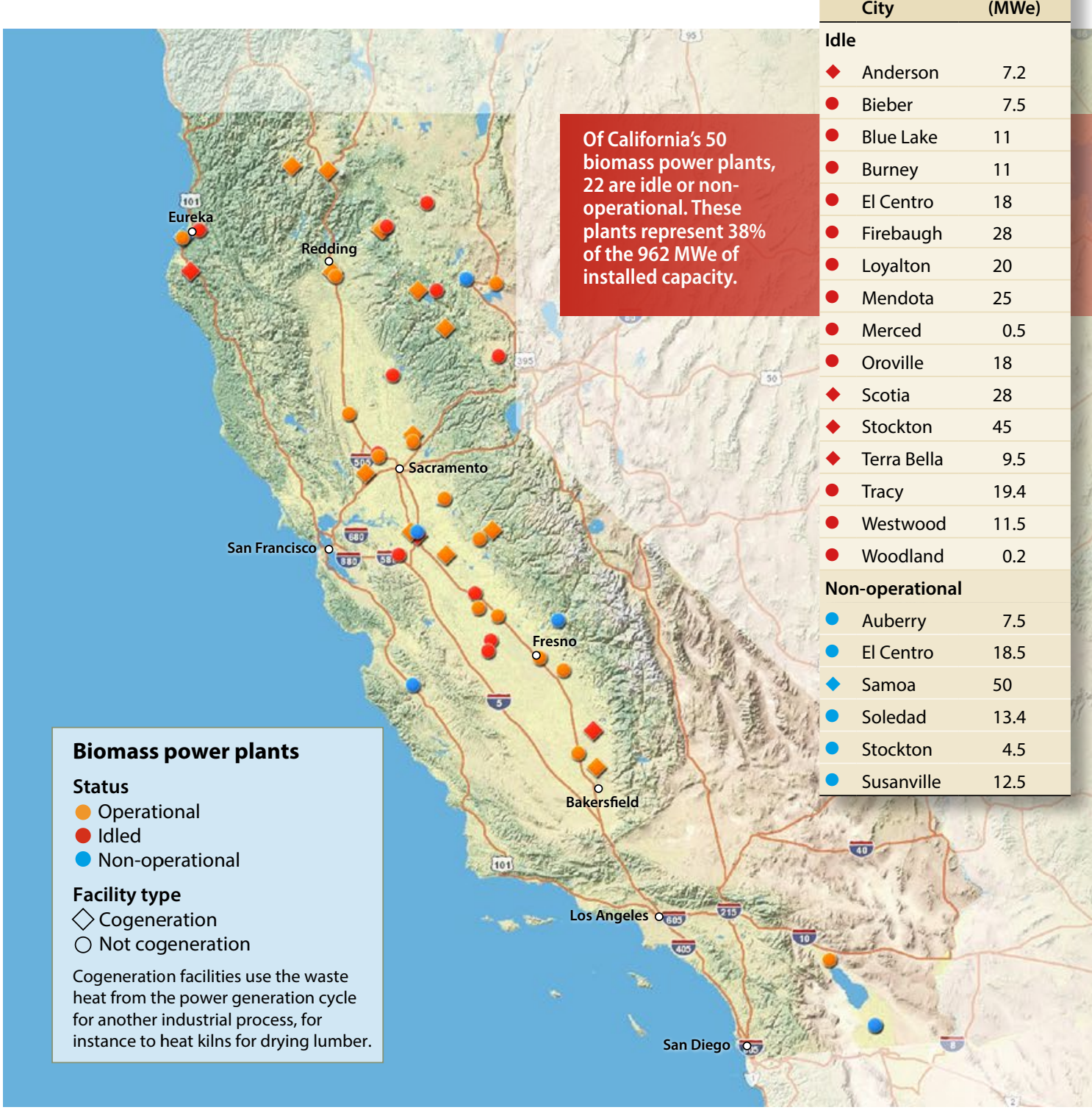

Forests will play a central role in meeting the state's goals for reducing greenhouse gas emissions both through sequestration and through the responsible use of wood in place of materials and energy sources with much greater climate impact. Forests can be used to help produce alternative energy without losing their intrinsic value to us as humans as beautiful, wild places. We can turn wood waste into electricity without compromising the ability of our forests to provide essential habitat to the wide range of animal, bird and insect species that depend on them. Bioenergy is a critical component of ensuring forest health now and in California's future. CA

.

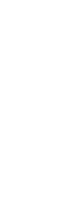

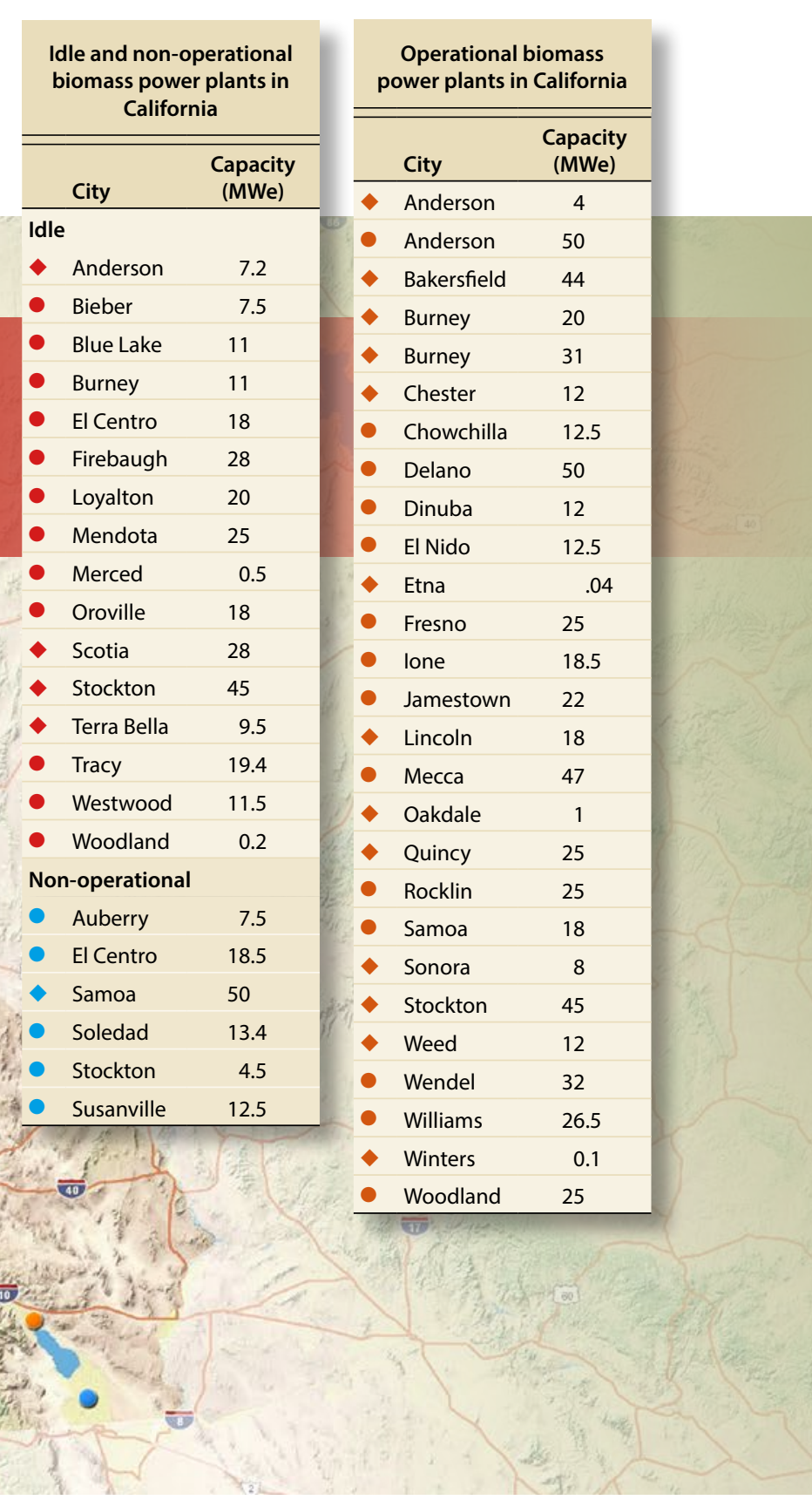

